This is an open access article distributed under the terms of the Creative Commons BY-NC-ND Licence

\title{
Foliar applications of spermidine improve foxtail millet seedling characteristics under salt stress
}

\author{
M. SUN, T. WANG, L. FAN, H. WANG, H. PAN, X. CUI, Y. LOU*, and Y. ZHUGE* \\ National Engineering Laboratory for Efficient Utilization of Soil and Fertilizer Resources, College of \\ Resources and Environment, Shandong Agricultural University, Tai'an City, Shandong 271018, P.R. China
}

\begin{abstract}
This study investigated the mitigating effects of spermidine (Spd) application on salinity-induced ion inbalance, physiological properties, and the expression of some genes in foxtail millet (Setaria italica L.). We observed 30-d-old seedlings maintained at a half-strength Hoagland solution (control), $1.0 \% \mathrm{NaCl}, 10,20$, and $40 \mu \mathrm{M} \mathrm{Spd}$, and 10, 20, and $40 \mu \mathrm{M} \mathrm{Spd}+1.0 \%(\mathrm{~m} / \mathrm{v}) \mathrm{NaCl}$ for $14 \mathrm{~d}$. The results show that salt stress significantly inhibited plant growth, and this was significantly ameliorated by Spd. The mass of the shoots and roots, content of chlorophyll $a$ and chlorophyll $b$, root activity, and $\mathrm{K}^{+}$content were higher whereas $\mathrm{Na}^{+}$content, $\mathrm{Na}^{+} / \mathrm{K}^{+}$ratio, relative electrolyte leakage, glutathione content, $\mathrm{H}_{2} \mathrm{O}_{2}$ content, activity of glutathione reductase (GR), and catalase (CAT) were lower after application of Spd in comparison with $\mathrm{NaCl}$ alone. The expression of $G R$, ascorbate peroxidase, $C A T$, and superoxide dismutase genes also significantly decreased in salt stressed plants with Spd. This study has proved the role of Spd in alleviating salt stress in foxtail millet and identified that $20 \mu \mathrm{M}$ Spd was most effective.
\end{abstract}

Additional key words: antioxidant enzymes, gene expression, reactive oxygen species, root activity, soil salinity.

\section{Introduction}

Soil salinity affects plant growth, crop productivity, and quality, and hence, is one of the most important problems for the future of global agriculture (Shahbaz and Ashraf 2013). Approximately $20 \%$ of irrigated lands worldwide are affected by salinity (Zhao et al. 2017). Salt stress leads to the disruption of enzymes and other macromolecules, the damage to cell organelles, and the changes in photosynthesis and respiration (Porcel et al. 2016). Furthermore, drought stress and nutrient imbalances in plants are also induced by soil salinity, and lead to the accumulation of $\mathrm{Na}^{+}$and the impairment of $\mathrm{K}^{+}$uptake (Ruiz-Lozano et al. 2012). Abnormally high cystolic $\mathrm{Na}^{+} / \mathrm{K}^{+}$ratio triggers the inhibition of protein synthesis and enzymatic activities (Porcel et al. 2016). The saline conditions have also resulted in the generation of excessive reactive oxygen species (ROS) that leads to chlorophyll (Chl) degradation, membrane lipid peroxidation, and membrane fluidity reductions (Taïbi et al. 2016). The ROS also exert effects on several other macromolecules, such as proteins and nucleic acids (Ahmad et al. 2010). However, plants have developed several protective mechanisms and both enzymatic and non-enzymatic antioxidants are involved in scavenging ROS (Abd Allah et al. 2015). Research has widely documented that superoxide dismutase (SOD), catalase (CAT), ascorbate peroxidase (APX), and glutathione reductase (GR), detoxify ROS (Farhangi-Abriz and Torabian 2017). In addition, the accumulation of osmolytes, such as proline, glycine betaine, soluble proteins, and soluble sugars, is another strategy to mitigate osmotic stress provoked by salinity (Lou et al. 2019). To date, various methods have been used to improve cultivation of plants in saline-alkali soils and some systems for their efficient exploitation have been established. One approach is the selection of more salt-tolerant crops.

Foxtail millet (Setaria italica L.), a perennial C4 grass that belongs to the Poaceae family, subfamily Panicoideae, tribe Paniceae (Daverdin et al. 2015), was recognized as a particularly important cereal and fodder crop that is cultivated widely in arid and semi-arid

Submitted 8 June 2019, last revision 26 November 2019, accepted 17 December 2019.

Abbreviations: APX - ascorbate peroxidase; CAT - catalase; Chl - chlorophyll; EL - electrolyte leakage; GR - glutathione reductase; GSH - glutathione; $\mathrm{O}_{2}^{-}$- superoxide anion; ROS - reactive oxygen species; Spd - spermidine; SOD - superoxide dismutase; TP - total protein; TTC - 2,3,5-triphenyltetrazolium chloride; TTF - triphenylformazan.

Acknowledgements: This work was supported by the Major Science and Technology Innovation Project of Shandong Province (No. 2017CXGC0306), the Modern Agriculture Industrial Technology Systems Project of Shandong Province (No. SDAIT-15-04), the Postdoctoral Innovation Project of Shandong Province (No. 201603052), and the Key Research and Development Program (Industry Key Technology) of Shandong Province (No. 2016CYJS05A02).

* Corresponding authors; e-mails: yanhonglou1985@163.com, zhugeyp@sdau.edu.cn 
regions (Zhang and Liu 2015). With excellent drought and salinity tolerance, foxtail millet has the potential to be cultivated in saline-alkali soils (Sudhakar et al. 2015). Furthermore, the demand for foxtail millet has increased significantly as societies focus on healthier diets, and it offers a high nutrient content, including starch, amylose, protein, vitamins, and fatty acids (Wang et al. 2017). Veeranagamallaiah et al. (2008) reported that the seedling growth of foxtail millet was inhibited significantly with $100 \mathrm{mM} \mathrm{NaCl}$ and then linearly decreased with increasing salt concentrations, and similar results were found for their dry mass. Unfortunately, there is little documented how to improved its salt tolerance.

Spermidine (Spd) acts as a growth regulator and is a ubiquitous low molecular mass aliphatic nitrogen compound that is present in animals, plants, and bacteria (Sang et al. 2016). Application of Spd is known to elicit several physiological, histochemical, and biochemical effects. Fariduddin et al. (2018) revealed the ameliorative role of Spd on Lycopersicon esculentum, as $1.0 \mathrm{mM} \mathrm{Spd}$ successfully restored the negative effects induced by salt stress. Similar results with the application of Spd were also found for rice under heat stress (Tang et al. 2018), Boehmeria nivea under $\mathrm{Cd}^{2+}$ stress (Gong et al. 2016), creeping bentgrass under drought stress (Zhou et al. 2015), and mung bean under low temperature stress (Nahar et al. 2015). However, the optimum concentration of Spd for damage alleviation in plants under abiotic stress varied in individual crops (Lou et al. 2018), and little is known about the regulatory mechanisms of Spd on plant physiological and biochemical responses ( $\mathrm{Li}$ et al. 2015).

In the present study, different concentration of Spd were applied to foxtail millet seedlings to investigate whether exogenous Spd could improve foxtail millet resistance to salt stress by analyzing plant growth, antioxidant enzyme activity, root activity, ion balance, and gene expression. The findings of this work could provide a new theoretical approach for understanding the physiological basis of the Spd-alleviation of saline damage and could promote the development and expansion of the foxtail millet cultivation on saline-alkali soils.

\section{Material and methods}

Plants and treatments: The seeds of foxtail millet (Setaria italica L.) cultivar Jingu No. 2 were obtained from the Center of Crop Germplasm Resources, Institute of Crop Science, Chinese Academy of Agricultural Sciences, Beijing, China. Disposable plastic cups (upper diameter $6.8 \mathrm{~cm}$, lower diameter $4.8 \mathrm{~cm}$, height $7.4 \mathrm{~cm}$ ) were filled with moistened sterile sand ( $<1 \mathrm{~mm}$ particle size). To drain the excess water and maintain good soil aeration, five holes (diameter of $5 \mathrm{~mm}$ ) were drilled in the base of each cup, and forty seeds were sown. The cups were arranged randomly in a greenhouse and irrigated with $10 \mathrm{~cm}^{3}$ of a half-strength Hoagland solution every $2 \mathrm{~d}$. After $30 \mathrm{~d}$ of cultivation, the seedlings were transferred to a growth chamber (Adaptis-A1000, Conviron, Shanghai, China), with a 16-h photoperiod, temperatures of $25 / 20{ }^{\circ} \mathrm{C}$ (day/night), a $75 \%$ relative humidity, and a photon flux density of $300 \mu \mathrm{mol} \mathrm{m} \mathrm{m}^{-2} \mathrm{~s}^{-1}$ at plant height, and cultivated $4 \mathrm{~d}$ for adaption. Then, eight different treatments were applied: CK - only a half-strength Hoagland solution; T1 $1.0 \%(\mathrm{~m} / \mathrm{v}) \mathrm{NaCl} ; \mathrm{T} 2$ - $10 \mu \mathrm{M} \mathrm{Spd}$; T3 - $10 \mu \mathrm{M}$ Spd + $1.0 \%(\mathrm{~m} / \mathrm{v}) \mathrm{NaCl} ; \mathrm{T} 4-20 \mu \mathrm{M}$ Spd; T5 - $20 \mu \mathrm{M}$ Spd + $1.0 \%(\mathrm{~m} / \mathrm{v}) \mathrm{NaCl}$; $\mathrm{T} 6$ - $40 \mu \mathrm{M} \mathrm{Spd}$; and T7 - $40 \mu \mathrm{M} \mathrm{Spd}+$ $1.0 \%(\mathrm{~m} / \mathrm{v}) \mathrm{NaCl}$. For all treatments, $\mathrm{NaCl}$ was dissolved in a half-strength Hoagland nutrient solution. Spermidine was mixed with water and applied via spray $\left(30 \mathrm{~cm}^{3}\right.$ per cup, and equal amounts of double distilled $\mathrm{H}_{2} \mathrm{O}$ were applied to the treatments without $\mathrm{Spd}$ ). All seedlings were arranged randomly and cultivated for $14 \mathrm{~d}$. Each treatmen was performed in triplicate. Ten seedlings were selected randomly and their shoot heights, root lengths, and fresh masses were individually determined.

Ion content: Fresh shoots and roots were oven dried at $105{ }^{\circ} \mathrm{C}$ for $30 \mathrm{~min}$, and then at $80^{\circ} \mathrm{C}$ to a constant mass. The dried samples were ground into a powder and then passed through a sieve $(\leq 0.25 \mathrm{~mm})$. Sub-samples $(0.1 \mathrm{~g})$ were weighed and digested with concentrated $\mathrm{H}_{2} \mathrm{SO}_{4}$ $(98 \%, \mathrm{~m} / \mathrm{m})$ and $\mathrm{H}_{2} \mathrm{O}_{2}(30 \%, \mathrm{v} / \mathrm{v}), 2: 1 \mathrm{v} / \mathrm{v}$, at $370{ }^{\circ} \mathrm{C}$ until a clear solution was obtained. The $\mathrm{K}^{+}$and $\mathrm{Na}^{+}$content were determined by flame photometry (AP1500, AoPu, Shanghai, China) following the method of Kalhoro et al. (2016); the $\mathrm{Na}^{+} / \mathrm{K}^{+}$ratio was also calculated.

Chlorophyll content: For Chl content determination, fresh leaf material $(0.1 \mathrm{~g})$ was transferred into a $20 \mathrm{~cm}^{3}$ cuvette filled with $10 \mathrm{~cm}^{3}$ of dimethyl sulfoxide (DMSO). All cuvettes were kept in the dark at $20{ }^{\circ} \mathrm{C}$ for $3 \mathrm{~d}$ and shaken every $24 \mathrm{~h}$. The supernatants were diluted $3 \times$ with DMSO and absorptions measured at 663 and $645 \mathrm{~nm}$ using a spectrophotometer (UV-2600, UNICO Instruments, Shanghai, China) according to Rasool et al. (2013).

Electrolyte leakage (EL) was assessed using an electrical conductivity meter, as described by Jungklang et al. (2017). Fresh leaf material $(0.1 \mathrm{~g})$ was cut into $0.5 \mathrm{~cm}$ segments. Then, all segments were immersed in $10 \mathrm{~cm}^{3}$ of deionized water and shaken at $25^{\circ} \mathrm{C}$ for $12 \mathrm{~h}$. The initial conductivity $\left(\mathrm{C}_{\mathrm{i}}\right)$ of the soaking solution was measured using a conductance meter (JENCO-3173, Jenco Instruments, San Diego, CA, USA). The samples were then heated in a boiling water bath for $30 \mathrm{~min}$, cooled to room temperature, shaken, and the final electrical conductivity $\left(\mathrm{C}_{\max }\right)$ measured. Relative EL was calculated as follows: $\mathrm{EL}=\left(\mathrm{C}_{\mathrm{i}} / \mathrm{C}_{\max }\right) \times 100 \%$.

Hydrogen peroxide, total protein, and glutathione content, CAT and GR activities, and $\mathrm{O}_{2}{ }^{--}$production were determined using a spectrophotometer $(U V-2600)$, as described by Han et al. (2019). Fresh leaf material (0.2 g) was shredded and grounded with $1.8 \mathrm{~cm}^{3}$ of physiological saline in liquid nitrogen in an ice bath. The homogenate was transferred into $2-\mathrm{cm}^{3}$ centrifuge tubes and centrifuged at $12000 \mathrm{~g}$ and $4{ }^{\circ} \mathrm{C}$ for $15 \mathrm{~min}$. The supernatants were collected and analyzed with $A$ 064-1, A 045-2, A 006-1, A 007-1, A 062, and $A 052$ assay kits (Nanjing Jiancheng 
Bioengineering Institute, Nanjing, China). The absorbance of the reaction solution was determined at $405 \mathrm{~nm}$ for hydrogen peroxide, at $595 \mathrm{~nm}$ for total protein (TP), at $420 \mathrm{~nm}$ for glutathione (GSH), at $240 \mathrm{~nm}$ for CAT, at $340 \mathrm{~nm}$ for $\mathrm{GR}$, and at $550 \mathrm{~nm}$ for $\mathrm{O}_{2}-{ }^{-}$production. One unit of GR activity was defined as $1 \mathrm{mmol}$ of NADPH consumed per minute per gram of protein, one unit of CAT activity was defined as $1 \mu \mathrm{mol}$ of $\mathrm{H}_{2} \mathrm{O}_{2}$ consumed per minute per gram of protein, and the $\mathrm{O}_{2}{ }^{-}$production rate was calculated as the amount of $\mathrm{O}_{2}{ }^{-}(\mu \mathrm{g})$ evolved per gram of tissue protein.

Root activity was assessed according to the method described by Zhang et al. (2016) with slight modifications. The roots were washed and dried with filter paper. Thereafter, $0.5 \mathrm{~g}$ roots samples were placed in $50-\mathrm{cm}^{3}$ beakers where $5 \mathrm{~cm}^{3}$ of $0.1 \mathrm{M}$ phosphate buffer saline (PBS; pH 7.0) and $5 \mathrm{~cm}^{3}$ of $0.4 \%(\mathrm{~m} / \mathrm{v})$ 2,3,5-triphenyltetrazolium chloride (TTC) were added. The roots were fully immersed at $37^{\circ} \mathrm{C}$ for $1 \mathrm{~h}$. Then, to stop the reaction, $2 \mathrm{~cm}^{3}$ of $1 \mathrm{M}$ sulfuric acid was added, and the root sample removed from the beaker and dried with filter paper. The roots were ground with $10 \mathrm{~cm}^{3}$ ethyl acetate, a small amount of quartz sand was added for the extraction of TTC, the red triphenylformazan (TTF) was transferred into a test tube, and the absorption at $485 \mathrm{~nm}$ was measured using a spectrophotometer (UV-2600). Ethyl acetate was employed as the blank reference, and the absorbance was determined. A standard curve was then generated to determine the amount of reduced tetrazole which characterizes root activity.

Spermidine content: For Spd content analysis, dried samples $(1.0 \mathrm{~g})$ were weighed, transferred into tubes, and $1.0 \mathrm{~cm}^{3}$ of $5 \%(\mathrm{~m} / \mathrm{v})$ ice perchloric acid was added. Then, the mixture was immersed in an ice bath and shaken for $2 \mathrm{~h}$ and then centrifuged at $12000 \mathrm{~g}$ for $30 \mathrm{~min}$. Then, $0.5 \mathrm{~cm}^{3}$ of the supernatant was removed and added to $1.0 \mathrm{~cm}^{3}$ of $2 \mathrm{M} \mathrm{NaOH}$ solution followed by the addition of $0.015 \mathrm{~cm}^{3}$ of benzoyl chloride, vortexed for $20 \mathrm{~s}$ and then kept in a warm bath at $30{ }^{\circ} \mathrm{C}$ for $20 \mathrm{~min}$. Next, $2.0 \mathrm{~cm}^{3}$ of saturated $\mathrm{NaCl}$ and $2.0 \mathrm{~cm}^{3}$ of ice diethyl ether were added and vortexed for $20 \mathrm{~s}$ and centrifuged for $5 \mathrm{~min}$. Next, $1.0 \mathrm{~cm}^{3}$ of the ether phase was evaporated to dryness in a $37^{\circ} \mathrm{C}$ water bath, and then $0.2 \mathrm{~cm}^{3}$ of chromatographic methanol was added and passed through a $0.22 \mu \mathrm{m}$ filter.
The LC20 (Shimadzu, Kyoto, Japan) liquid chromatograph $V W D$ detector was employed to determine $\mathrm{Spd}$, and the high performance liquid chromatography conditions were: E-clipse Plus C18 $(250 \mathrm{~mm} \times 4.6 \mathrm{~mm}, 5 \mu \mathrm{m})$ reversed phase column; methanol:acetonitrile:water 60.5:2.5:37 (volume ratio); flow rate $0.8 \mathrm{~cm}^{3} \mathrm{~min}^{-1}$; temperature $30^{\circ} \mathrm{C}$; detection wavelength $254 \mathrm{~nm}$; injection volume $0.01 \mathrm{~cm}^{3}$.

Gene expression analysis with reverse-transcription quantitative PCR: Two segments of fresh leaves were harvested after Spd was applied for 0, 2, 4, 6, 8, 10, and $12 \mathrm{~h}$ and pulverized with liquid nitrogen. Total RNA was extracted with TRIzol reagent (Invitrogen, Carlsbad, CA, USA) according to the method of $\mathrm{Hu}$ et al. (2016). The first-strand cDNA was synthesized and gDNA removed using the $A Q 141$ kit. The reaction system consisted of a template $\left(10 \mathrm{pg}^{-1} \mu \mathrm{g}\right)$, primer, $2 \times$ TransSart Tip Green qPCR SuperMix, passive reference dye, and $\mathrm{dd}_{2} \mathrm{O}$. Reverse transcription PCR amplification was executed in two steps using the following conditions: amplification at $94{ }^{\circ} \mathrm{C}$ for $30 \mathrm{~s}$, then $40-45$ cycles of $94{ }^{\circ} \mathrm{C}$ for $15 \mathrm{~s}$, and $60{ }^{\circ} \mathrm{C}$ for $20 \mathrm{~s}$. All PCR amplification data were analyzed in Opticon Monitor v. 2.03 (MJ Research, Cambridge, MA, USA). The primer sequences are shown in Table 1 Suppl.

Statistical analyses: Experimental data are the averages of three replications and were subjected to ANOVA in SPSS v. 21.0 (IBM Corp, Armonk, NY, USA). Statistical significance was assessed using the least significant difference (LSD) test at $P \leq 0.05$. Diagrams were generated using OriginPro 2019 software (Originlab Corp., USA) and GraphPad software (GraphPad Corp., USA).

\section{Results}

Significant reductions were observed in the shoot mass $(34.63 \%)$, root mass $(44.71 \%)$, plant height $(35.89 \%)$, and root length $(26.19 \%)$ when the plants were exposed to the $1.0 \%(\mathrm{~m} / \mathrm{v}) \mathrm{NaCl}$ alone, relative to those in the non$\mathrm{NaCl}$ treatments (Figs. 1 and 2). Meanwhile, no negative effects were detected on these parameters when Spd alone was applied. However, higher shoot mass, root mass, and plant height were detected at $\mathrm{NaCl}+\mathrm{Spd}$ treatments than at $\mathrm{NaCl}$ alone. There was notably lower root mass (a $11.17 \%$ decrease) under the $\mathrm{T} 7$ treatment compared with that under

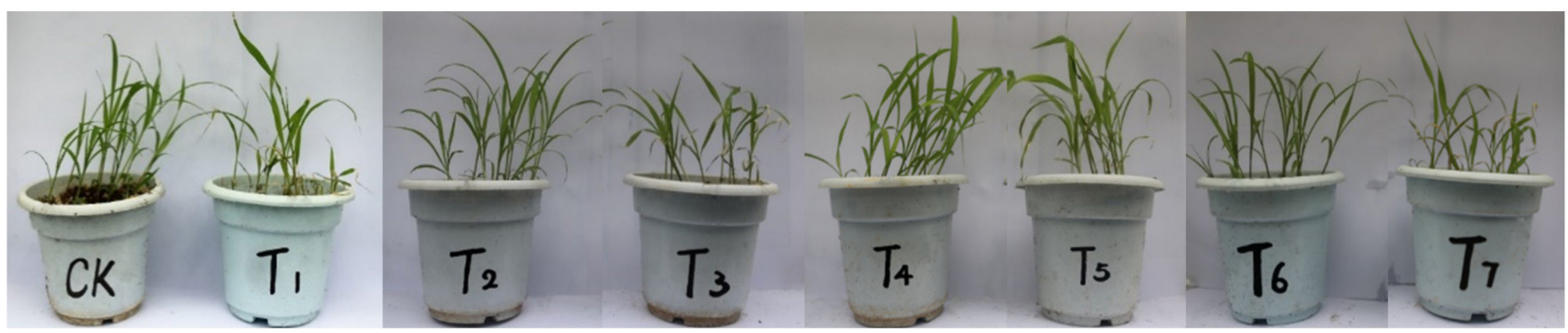

Fig. 1. Photographs of foxtail millet. Thirty-day-old seedlings were maintained in eight treatments: CK -- a half-strength Hoagland solution, $\mathrm{T} 1-1.0 \%(\mathrm{~m} / \mathrm{v}) \mathrm{NaCl}, \mathrm{T} 2-10 \mu \mathrm{M} \mathrm{Spd}, \mathrm{T} 3-10 \mu \mathrm{M} \mathrm{Spd}+1.0 \%(\mathrm{~m} / \mathrm{v}) \mathrm{NaCl}, \mathrm{T} 4-20 \mu \mathrm{M} \mathrm{Spd}, \mathrm{T} 5-20 \mu \mathrm{M} \mathrm{Spd}+1.0 \%(\mathrm{~m} / \mathrm{v})$ $\mathrm{NaCl}, \mathrm{T} 6-40 \mu \mathrm{M} \mathrm{Spd}$, and $\mathrm{T} 7-40 \mu \mathrm{M} \mathrm{Spd}+1.0 \%(\mathrm{~m} / \mathrm{v}) \mathrm{NaCl}$ for $14 \mathrm{~d}$. 


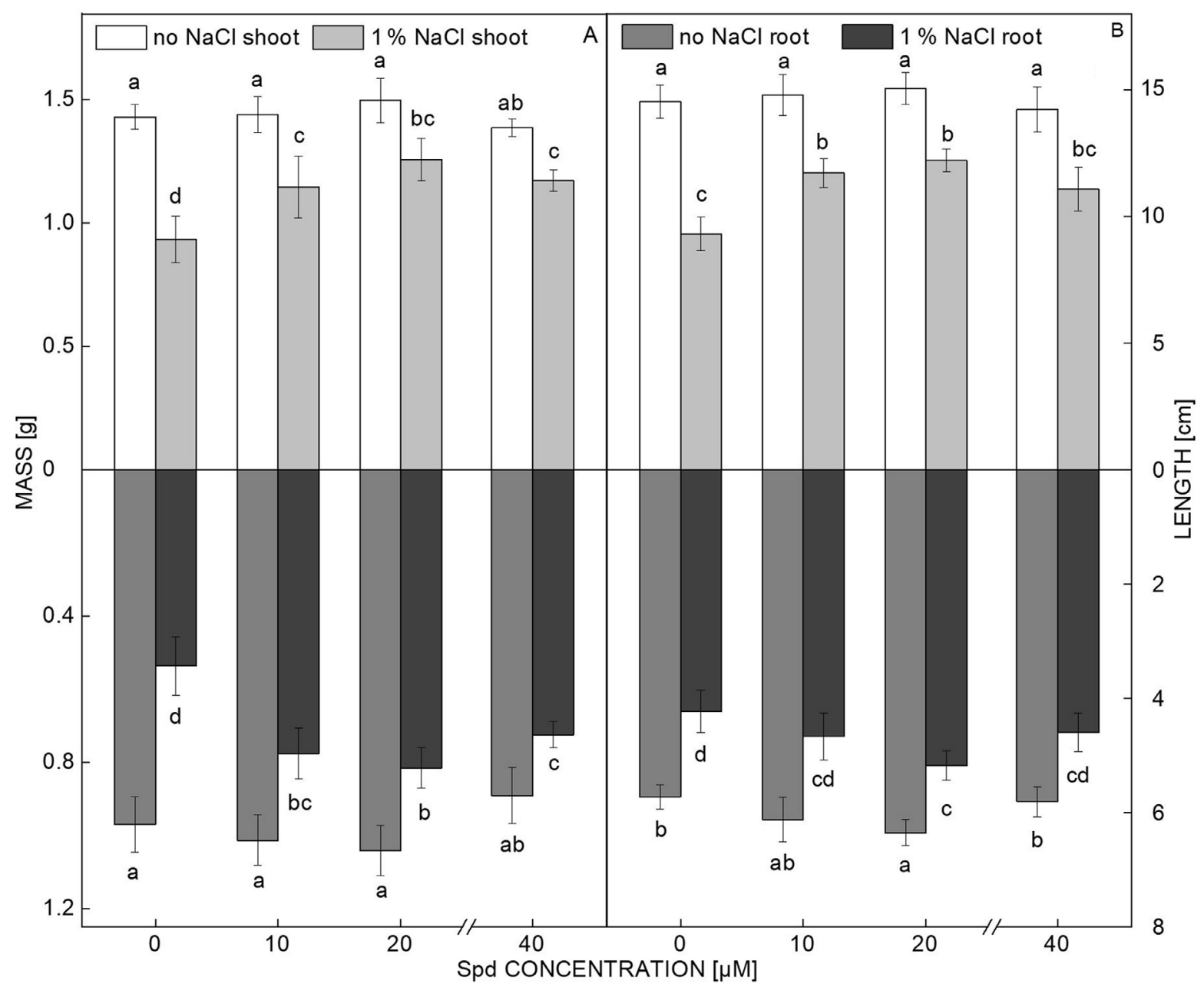

Fig. 2. Effects of spermidine (Spd) on growth of foxtail millet. $A$ - Shoot mass and root mass, $B$ - plant height and root length. Means \pm $\mathrm{SDs}, n=3$; different letters indicate significant differences at $P \leq 0.05$.

the T5 treatment. Meanwhile, no significant differences in root length were determined among T1, T3, T7 treatments, and higher root length at $\mathrm{T} 5$ relative to $\mathrm{T} 1$ (with $22.48 \%$ increase).

The Chl $a$, Chl $b$, and Chl $a+b$ content was significantly reduced when the plants were exposed to $\mathrm{NaCl}$ alone (Fig. 3A). However, only 20 and $40 \mu \mathrm{M} \mathrm{Spd} \mathrm{in} \mathrm{combination}$ with $\mathrm{NaCl}$ decreased the Chl $a(12.44-16.54 \%)$ and Chl $a+b(10.11-10.95 \%)$ content, relative to the control treatment. Meanwhile, no significant differences in the $\mathrm{Chl} a$ and $\mathrm{Ch} a+b$ content were observed between the salt and non-salt treatments when using the $10 \mu \mathrm{M} \mathrm{Spd}$ applications, and there were no remarkable effects on Chl $b$ content under the salt stress conditions relative to the non-salt stress treatments, when using various Spd concentrations $(10,20$, and $40 \mu \mathrm{M})$. Notably, Chl $a$ and Chl $a+b$ content in treatments T4 and T5 was higher than that in CK and T1. Furthermore, $\mathrm{Chl} b$ and $\mathrm{Chl} a+b$ content in T3 and T7 was higher than in T1 treatment.

Significant reduction in TP content in T1 (30.02\%) relative to $\mathrm{CK}$ was detected, and similar results were observed between salt treated and non-salt treated plants when they were exposed to the various concentrations of Spd (Fig. 3B). The $20 \mu \mathrm{M}$ Spd application increased TP content significantly compared with T1, and no significant differences were determined among T1, T3, and $\mathrm{T} 5$.

Under salt stress, relative electrolyte leakage (REL) in the leaves of the foxtail millet increased significantly compared with that in the control, and the increase was observed also after Spd application (Fig. 3C). Compared to T1, the Spd application treatments T3, T5, and T7 reduced REL by $21.86,37.29$, and $23.71 \%$, respectively. Meanwhile, the REL in T5 was lower than in T3 and T7, and there were no significant differences between T3 and T7. Furthermore, no significant effects on REL were detected among the various Spd treatments (CK, T2, T4, and T6) in the absence of salinity.

The $1.0 \%(\mathrm{~m} / \mathrm{v}) \mathrm{NaCl}$ alone reduced the root activity significantly (by $37.42 \%$ ) compared with that in the CK treatment (Fig. 3D). Fortunately, the root activities in T3, T5, and T7 were higher $(33.35,47.78$, and $37.11 \%$ respectively) in comparison to $\mathrm{T} 1$ treatment. In addition, the root activity in the T5 was higher than in T3 and T7, and no significant differences were found between T3 and T7.

To study the adverse effects of $\mathrm{NaCl}$ on foxtail millet, we 


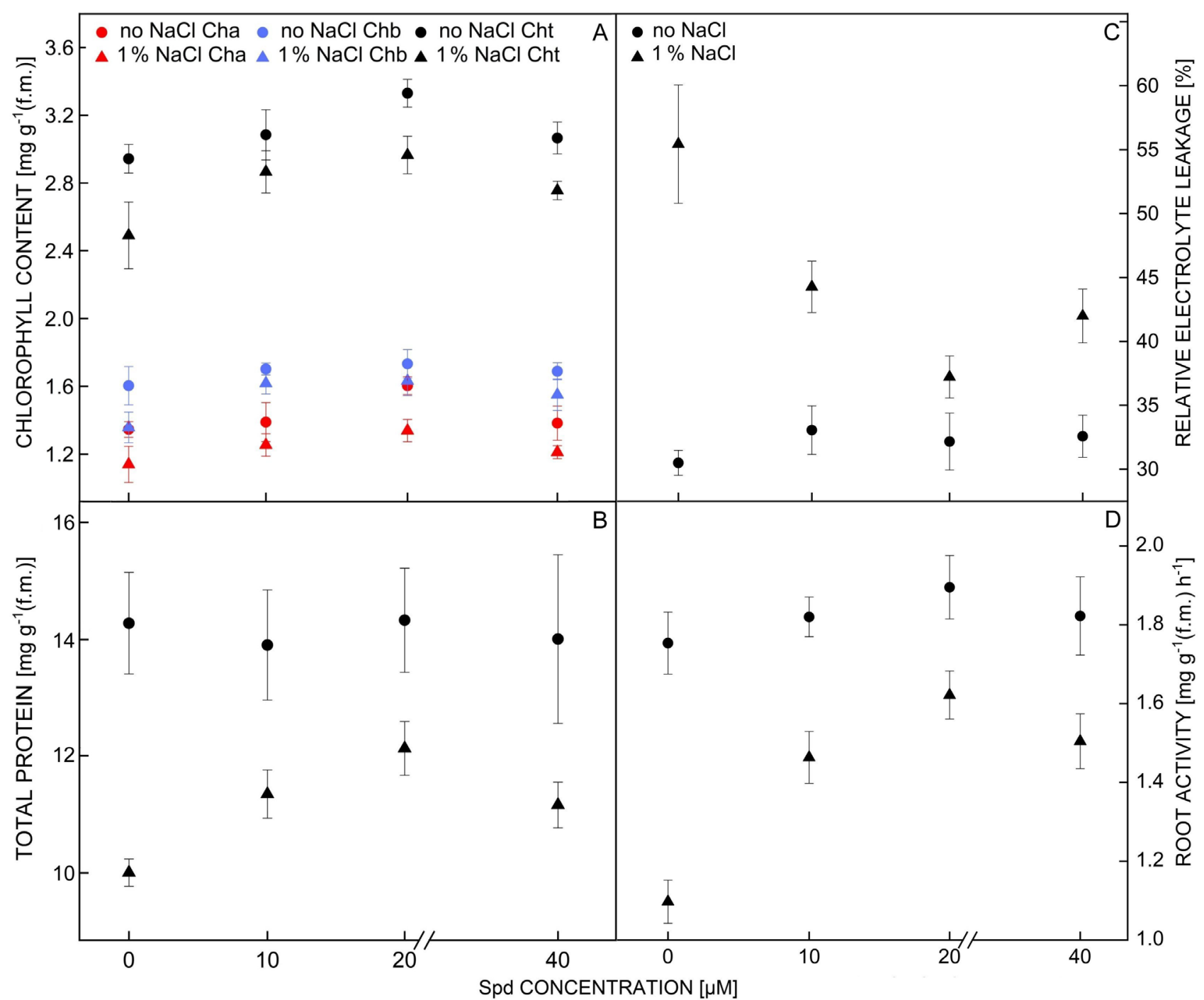

Fig. 3. Effects of spermidine (Spd) on chlorophyll content (A, Cha - chlorophyll $a$, Chb - chlorophyll $b$, Cht - total chlorophyll); total protein $(B)$; relative electrolyte leakage $(C)$, and root activity $(D)$ in foxtail millet. Means \pm SDs, $n=3$; different letters indicate significant differences at $P \leq 0.05$.

also determined the $\mathrm{Na}^{+}$and $\mathrm{K}^{+}$content and found that the $\mathrm{K}^{+}$content in the leaves was significantly lower $(36.12 \%)$ and the $\mathrm{Na}^{+}$content was significantly higher $(85.49 \%)$ in the T1 treatment compared with the CK (Fig. 4A-C). The Spd applications decreased the $\mathrm{Na}^{+}$content, and no significant differences were observed among the treatments T3, T5, and T7. However, the $\mathrm{K}^{+}$content in T3, T5, and T7 was increased markedly compared with the T1 treatment. No significant differences were detected among Spd concentrations. The excessive absorption of $\mathrm{Na}^{+}$, and the inhibition of $\mathrm{K}^{+}$uptake by salinity led to higher $\mathrm{Na}^{+} / \mathrm{K}^{+}$ratio in $\mathrm{T} 1$ relative to CK. However, the $\mathrm{Na}^{+} / \mathrm{K}^{+}$ ratios decreased with the Spd applications $(28.05,35.83$, and $33.12 \%$ for $\mathrm{T} 3, \mathrm{~T} 5$, and $\mathrm{T} 7$, respectively), when compared with $\mathrm{T} 1$. The $\mathrm{Na}^{+} / \mathrm{K}^{+}$ratios were lower in $\mathrm{T} 5$ and $\mathrm{T} 7$ than in T3, and no significant differences were detected between T5 and T7. However, the Spd applications led to higher $\mathrm{Na}^{+} / \mathrm{K}^{+}$ratios also when exposed to the non-salt stress conditions.
Under salt stress, Spd was synthesized by plants to cope with the detrimental damage, and as such, a higher Spd content of $32.80 \%$ was detected under the T1 treatment than in the CK (Fig. 5). Higher Spd content was also observed in the plants treated with the Spd, both without and with $1.0 \%(\mathrm{~m} / \mathrm{v}) \mathrm{NaCl}$. Furthermore, there was a higher Spd content under the T5 and T7 treatments than under T3, and under T4 and T6 than under T2. There were no significant differences in Spd content between T5 and $\mathrm{T} 7$, and $\mathrm{T} 4$ and $\mathrm{T} 6$, respectively.

The GSH content, $\mathrm{H}_{2} \mathrm{O}_{2}$ content, and $\mathrm{O}_{2}^{--}$activity were significantly increased in $\mathrm{T} 1$ treatment by $65.43,122.92$, and $36.68 \%$, respectively, compared to those in the CK treatment (Fig. 4D-F). However, the GSH content decreased by $18.79-27.96 \%$, and the $\mathrm{H}_{2} \mathrm{O}_{2}$ content by 20.12 - $25.33 \%$ after Spd application, relative to the T1 treatment. Regarding the $\mathrm{O}_{2}-$ activity, only that in T5 was higher than in T1, and there were no significant differences among T1, T3, and T7 treatments. In addition, 


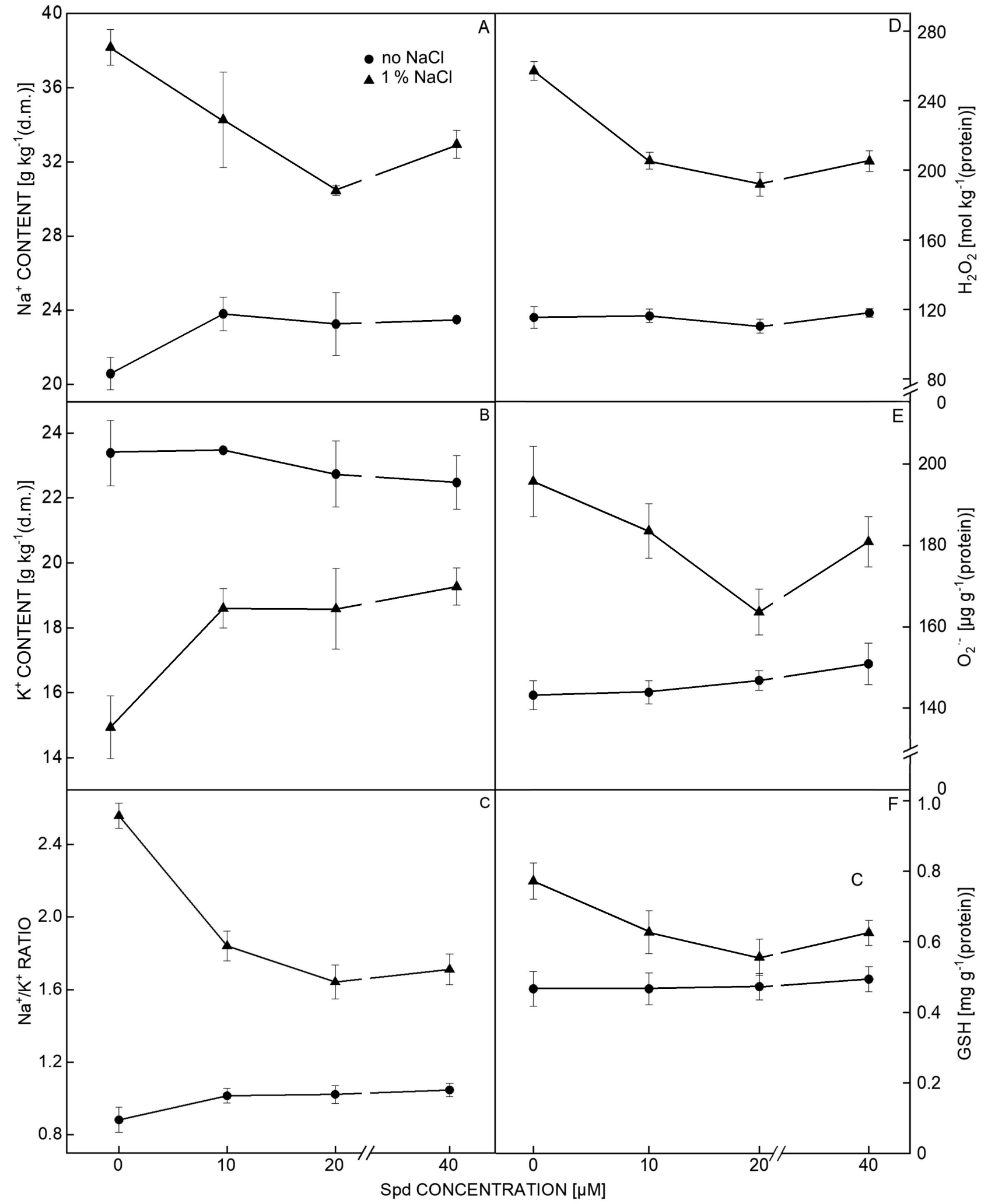

Fig. 4. Effects of spermidine (Spd) on $\mathrm{Na}^{+}$content $(A), \mathrm{K}^{+}$content $(B)$, and $\mathrm{Na}^{+} / \mathrm{K}^{+}$ratio $(C), \mathrm{H}_{2} \mathrm{O}_{2}(D), \mathrm{O}_{2}^{--}(E)$, and glutathione (GSH) $(F)$ in foxtail millet. Means \pm SDs, $n=3$; different letters indicate significant differences at $P \leq 0.05$. 


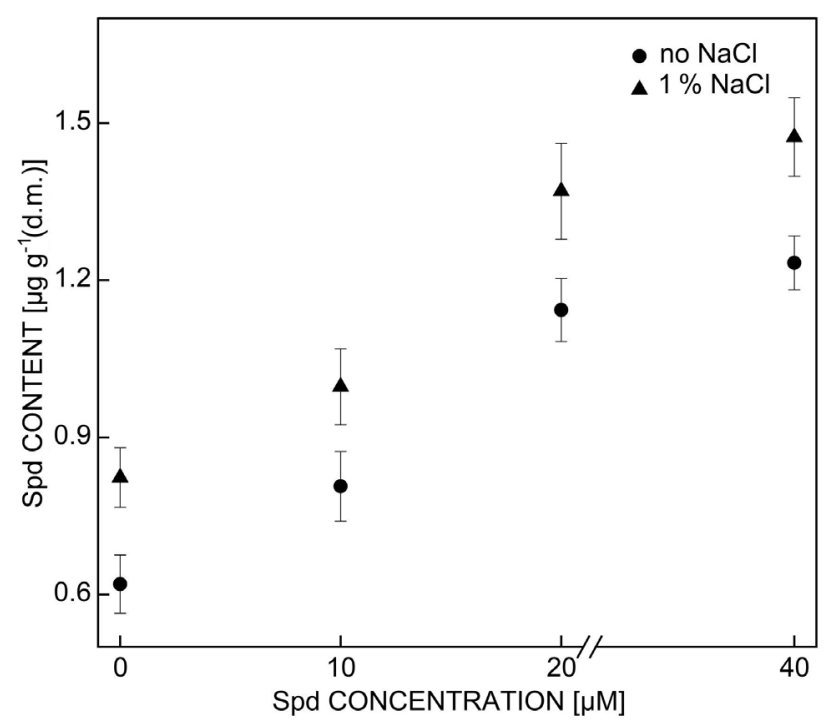

Fig. 5. Effects of spermidine (Spd) on Spd content in foxtail millet. Means \pm SDs, $n=3$; different letters indicate significant differences at $P \leq 0.05$.

the Spd application alone had no significant effects on GSH content, $\mathrm{H}_{2} \mathrm{O}_{2}$ content, and $\mathrm{O}_{2}{ }^{-}$activity.

Compared with those under $\mathrm{CK}$ treatment, the activities of GR and CAT were significantly increased due to the $1.0 \%(\mathrm{~m} / \mathrm{v}) \mathrm{NaCl}$ stress and increased by 57.35 and $64.39 \%$ in T1 relative to CK (Fig. 6). The Spd application decreased the GR and CAT activities by $10.42-17.80 \%$ and $9.03-22.70 \%$, respectively. The lower CAT activities were in $\mathrm{T} 5$ and $\mathrm{T} 7$ than in $\mathrm{T} 2$, and the difference between T5 and T7 were not significant. No significant differences in GR activity were observed among the T3, T5, and T7 treatments, and no remarkable effects on the activities of GR and CAT by the Spd alone.

The expression of $G R, A P X, C A T$, and $S O D$ genes were significantly increased in T1 compared with those in CK (by 1.39 - 2.73, $3.80-8.42,3.48$ - 4.73, and 2.85 - 5.35 times, respectively (Fig. 7). Lower $G R$ and $S O D$ expressions were detected after various $\mathrm{Spd}$ concentrations (T3, T5, and T7) than in T1 at 4, 6, 8, 10, and $12 \mathrm{~h}$. The $S O D$ expressions in $\mathrm{T} 5$ and $\mathrm{T} 7$ were lower than in $\mathrm{T} 1$ and $\mathrm{T} 3$ at $2 \mathrm{~h}$, and $A P X$ and $C A T$ expressions decreased after Spd application relative to $\mathrm{T} 1$ at 2, 4, 6, 8, 10, and $12 \mathrm{~h}$. Notably, no significant effects Spd applications on the $G R$, $A P X, C A T$, and $S O D$ expressions were found under nonsaline conditions at $2-12 \mathrm{~h}$. There was a lower expression of $G R$ in T5 than in T3 at $10 \mathrm{~h}$, and in T3 and T7 at $12 \mathrm{~h}$. Among various Spd application treatments, T5 exposed to the $1.0 \%(\mathrm{~m} / \mathrm{v}) \mathrm{NaCl}$ regime induced the lowest expression of $A P X$ and $S O D$. Furthermore, $C A T$ expression was lower in $\mathrm{T} 5$ than in $\mathrm{T} 3$ with no significant difference between $\mathrm{T} 5$ and $\mathrm{T} 7 \mathrm{at} 10$ and $12 \mathrm{~h}$.

\section{Discussion}

Foxtail millet is widely cultivated for its high yield, outstanding quality, and economic value, and it can be

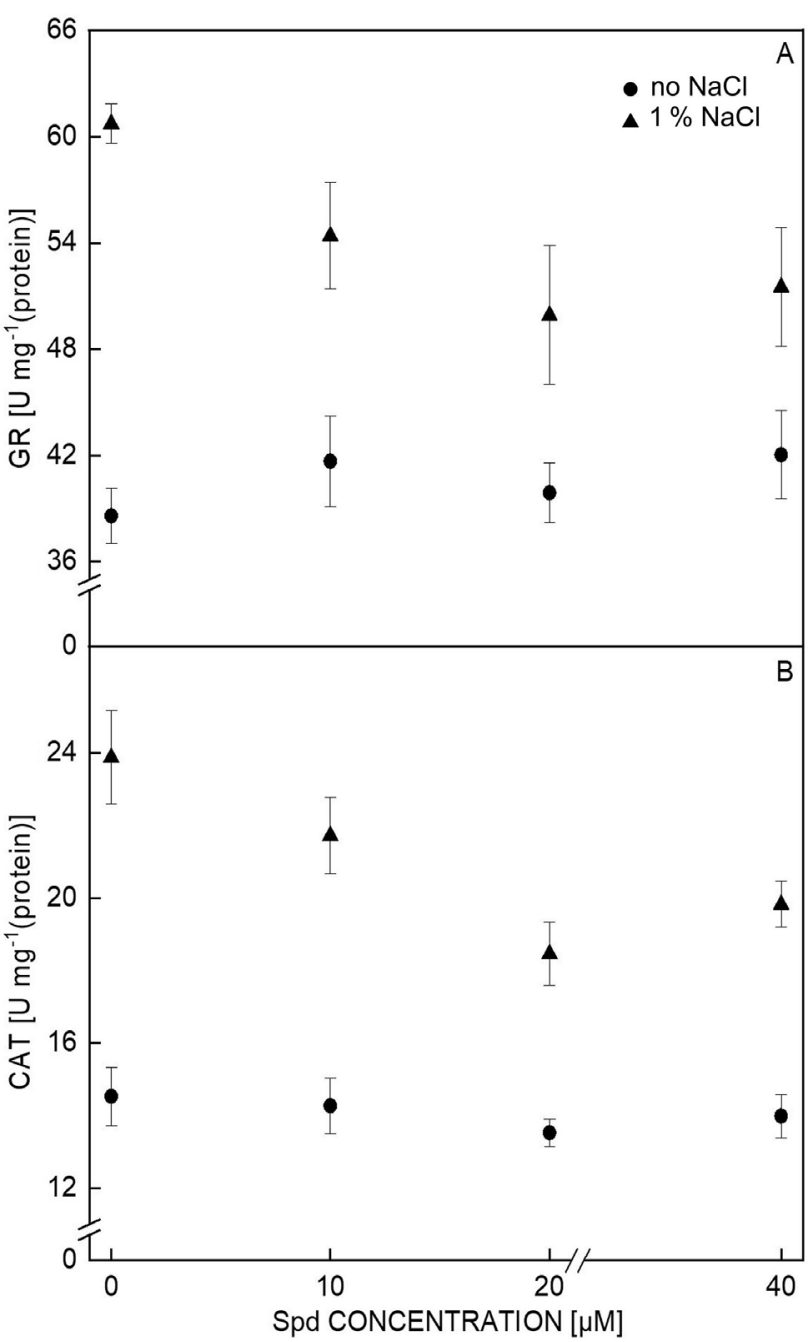

Fig. 6. Effects of spermidine (Spd) on antioxidant activity of foxtail millet. $A$ - glutathione reductase (GR); $B$ - catalase (CAT). Means \pm SDs, $n=3$; different letters indicate significant differences at $P \leq 0.05$.

widely grown in saline-alkali soils owing to its excellent salt tolerance (Veeranagamallaiah et al. 2008). However, the growth and yield of foxtail millet are limited by high osmotic pressure and adverse effects of $\mathrm{Na}^{+}$and $\mathrm{Cl}^{-}$ (Talaat et al. 2015), which induce imbalances in various physiological and biochemical processes. The toxicity of $\mathrm{Na}^{+}$accumulation in plants is considered a major problem associated with salinity stress. Previous reports have demonstrated that $\mathrm{Na}^{+}$in substrate causes $\mathrm{K}^{+}$deficiencies by inhibiting $\mathrm{K}^{+}$uptake by plants (Liu et al. 2000), but maintaining a lower $\mathrm{Na}^{+} / \mathrm{K}^{+}$ratio is important. In the present study, we observed that the $\mathrm{Na}^{+} / \mathrm{K}^{+}$ratio increased by up to 1.68 -times when the plant was exposed to $1.0 \% \mathrm{NaCl}$. However, we noted that after addition of Spd, the $\mathrm{Na}^{+} / \mathrm{K}^{+}$ ratios decreased due to increased $\mathrm{K}^{+}$absorption maybe influencing competition with $\mathrm{Na}^{+}$at both the transport site and the binding site (Maathuis et al. 1999). Similar results were obtained in wheat by Zhang et al. (2016), where Spd treatments significantly increased $\mathrm{K}^{+}$content 


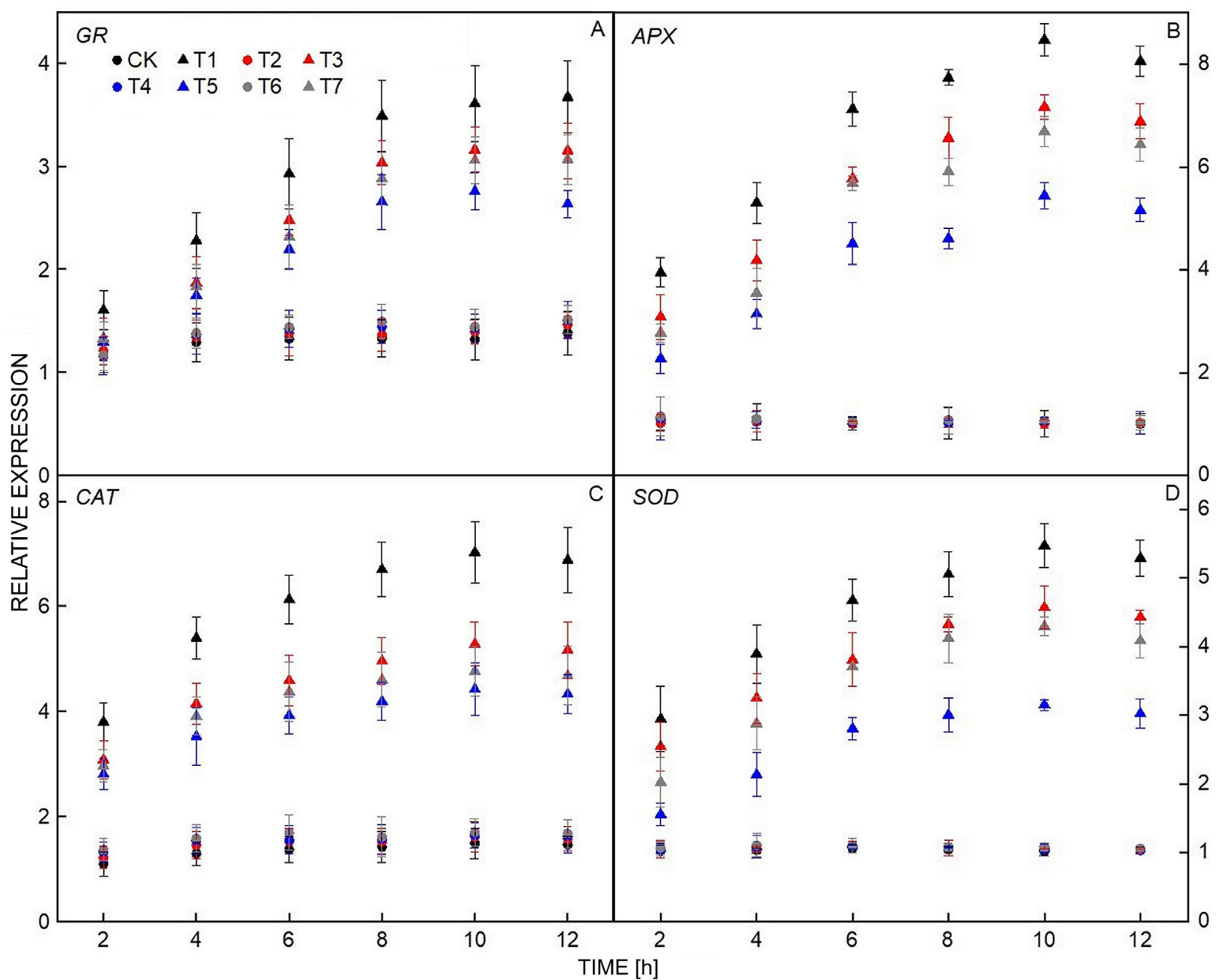

Fig. 7. Effects of spermidine on the glutathione reductase $(G R)(A)$, ascorbate peroxidases $(A P X)(B)$, catalase $(C A T)(C)$, and superoxide dismutase $(S O D)(D)$ gene expressions in foxtail millet.

and decreased $\mathrm{Na}^{+}$content.

As a comprehensive response index, biomass decrease is a reliable indicator for assessing the degree of damage and the tolerance ability of plants to salt stress. This study showed that the growth indexes (plant height, root length, shoot mass, and root mass) decreased significantly with salt stress. Meanwhile, this detrimental damage was alleviated by foliar applications of Spd, and the amelioration was non-dose dependent. Therefore, greater shoot mass, root mass, plant height, and root length were observed in the Spd-treated plants, compared with those not treated with Spd. Similar results were also found with Calendula officinalis (Baniasadi et al. 2018), maize, Arabidopsis (Chen et al. 2017), chrysanthemum (Zhang et al. 2016), and zoysiagrass (Li et al. 2016).

The photosynthetic pigment content of leaves is also an important indicator, reflecting the plant's photosynthetic capacity. However, chloroplast pigment content varies according to changing of various environmental factors. Present results showed that the Chl content decreased significantly under salt stress, consistent with the research of Dąbrowski et al. (2017) on perennial ryegrass. The Chl content increased with Spd application, especially Chl $a+b$ content.

Spermidine is a small aliphatic polyamine that occurs as ubiquitous polycation in higher plants and is recognized as a plant growth regulator (Satish et al. 2016). The content of Spd in plants can reflect the resistance of plants to abiotic stresses. To deal with salt stress, plants synthesize excess Spd, and higher Spd content was observed in plants treated with $1.0 \%(\mathrm{~m} / \mathrm{v}) \mathrm{NaCl}$, than in the control. We also found that spraying with Spd increased the content of Spd in foxtail millet and proved that the foliar application was an effective method to increase Spd content in plants.

In the present study, the TP content was reduced significantly in response to the salt stress conditions and was attributed to the oxidation of $\mathrm{Chl}$, damage to the chloroplast ultrastructure, and absorption of nutrients (Cherif-Silini et al. 2016). Fortunately, Spd applications increased the TP content. Similar results were obtained by Radhakrishnan et al. (2013) in cucumber plants treated with Spd, and the reason for this phenomenon is attributed to the effects of Spd application on the activities of enzymes responsible for protein metabolism.

It is well documented that excessive ROS are produced directly via the Haber-Weiss and Fenton reactions and can 
destroy proteins, nucleic acids, and enzymes (Buapet et al. 2019). The maintenance of an efficient antioxidant system is crucial for plants to protect themselves also under salinity (Saxena et al. 2016). Our results also demonstrated that excessive $\mathrm{H}_{2} \mathrm{O}_{2}$ was produced in plants under salt stress, nearly 2.23 times more under $\mathrm{NaCl}$ treatments than in the control. However, the GSH content, and CAT and GR activities were increased significantly and attributed to the defense mechanisms of plants to alleviate the oxidative stress-related damage. These results are consistent with the reports by Abd Allah et al. (2015) who suggested that the GSH content and CAT in Sesbania sesban increased with increasing salt concentrations. Nevertheless, the increased GR activity induced by salt stress in foxtail millet was significantly decreased by Spd, regardless of its concentration. In addition, the CAT activity was also reduced under Spd application. These results disagreed with those of Puyang et al. (2015), who indicated that the CAT activity in Kentucky bluegrass increased with Spd application. This phenomenon may be due to species differences that resulted in different $\mathrm{Spd}$ protection mechanisms. It is well-known that exposure to higher concentrations of $\mathrm{NaCl}$ induces metabolic imbalances in plant cells, thereby altering the amount and activities of different enzymes. Researchers have illustrated that salt stress can also lead to changes in respective gene expressions. By comparing the expressions of $A P X, C A T$, $G R$, and $S O D$ genes under salt stress alone and under addition of Spd, we concluded that Spd may play an important role in improving the salt-tolerance of foxtail millet. Our results indicated that the expressions of $A P X$, $C A T, G R$, and $S O D$ were up-regulated under salt stress conditions, similar to the results from $\mathrm{Hu}$ et al. (2011), who found that gene expressions were up-regulated with saline conditions in perennial ryegrass. Importantly, the expressions of $A P X, C A T, G R$, and $S O D$ were lowered by the application of Spd.

In summary, application of Spd of a certain concentration was effective at ameliorating the detrimental damage of foxtail millet caused by salt stress. The beneficial effects of $20 \mu \mathrm{M}$ Spd application may be attributed to inhibition of $\mathrm{Na}^{+}$absorption, promotion of $\mathrm{K}^{+}$absorption, and reduction of $\mathrm{Na}^{+} / \mathrm{K}^{+}$ratio. Spd also promoted the increase of total biomass, TP content, $\mathrm{Chl}$ content, and root activity. However, it decreased $\mathrm{H}_{2} \mathrm{O}_{2}$, and GSH content, GR, CAT, and $\mathrm{O}_{2}$ activity as well as expressions of $C A T, A P X, G R$, and $S O D$ genes.

\section{References}

Abd Allah, E.F., Hashem, A., Alqarawi, A.A., Bahkali, A.H., Alwhibi, M.S.: Enhancing growth performance and systemic acquires resistance of medicinal plant Sesbania sesban (L.) Merr using arbuscular mycorrhizal fungi under salt stress. Saudi J. biol. Sci. 22: 274-283, 2015.

Ahmad, P., Jaleel, C.A., Salem, M.A., Nabi, G., Sharma, S.: Roles of enzymatic and nonenzymatic antioxidants in plants during abiotic stress. - Crit. Rev. Biotechnol. 30: 161-175, 2010.

Baniasadi, F., Saffari, V.R., Moud, A.A.M.: Physiological and growth responses of Calendula officinalis L. plants to the interaction effects of polyamines and salt stress. - Sci. Hort. 234: 312-317, 2018.

Buapet, P., Mohammadi, N.S., Pernice, M., Kumar, M., Kuzhiumparambil, U., Ralph, P.J.: Excess copper promotes photoinhibition and modulates the expression of antioxidantrelated genes in Zostera muelleri. - Aquat. Toxicol. 207: 91100,2019

Chen, L., Liu, Y., Wu, G., Zhang, N., Shen, Q., Zhang, R.: Beneficial rhizobacterium Bacillus amyloliquefaciens SQR9 induces plant salt tolerance through spermidine production. Mol. Plant-Microbe Interact. 30: 423-432, 2017.

Cherif-Silini, H., Silini, A., Yahiaoui, B., Ouzari, I., Boudabous, A.: Phylogenetic and plant-growth-promoting characteristics of Bacillus isolated from the wheat rhizosphere. - Ann. Microbiol. 66: 1087-1097, 2016.

Dąbrowski, P., Kalaji, M.H., Baczewska, A.H., Pawluśkiewicz, B., Mastalerczuk, G., Borawska-Jarmułowicz, B., Paunov, M., Goltsev, V.: Delayed chlorophyll $a$ fluorescence, MR 820: and gas exchange changes in perennial ryegrass under salt stress. - J. Luminescence 183: 322-333, 2017.

Daverdin, G., Bahri, B.A., Wu, X.M., Serba, D.D., Tobias, C., Saha, M.C., Devos, K.M.: Comparative relationship and chromosome evolution in switch grass (Panicum virgatum) and its genomic model, foxtail millet (Setaria italica). BioEnergy Res. 8: 137-151, 2015.

Farhangi-Abriz, S., Torabian, S.: Antioxidant enzyme and osmotic adjustment changes in bean seedlings as affected by biochar under salt stress. - Ecotoxicol. Environ. Safety 137: 64-70, 2017.

Fariduddin, Q., Khan, T.A., Yusuf, M., Aafaqee, S.T., Khalil, R.R.A.E.: Ameliorative role of salicylic acid and spermidine in the presence of excess salt in Lycopersion esculentum. Photosynthetica 56: 750-762, 2018.

Gong, X., Liu, Y., Huang, D., Zeng, G., Liu, S., Tang, H., Zhou, L., Hu, X., Zhou, Y., Tan, X.: Effects of exogenous calcium and spermidine on cadmium stress moderation and metal accumulation in Boehmeria nivea (L.) Gaudich. - Environ. Sci. Pollut. Res. Int. 23: 8699-8708, 2016.

Han, F., Sun, M.J., He, W., Cui, X.M., Pan, H., Wang, H., Song, F.P., Lou, Y.H., Zhuge, Y.P.: Ameliorating effects of exogenous $\mathrm{Ca}^{2+}$ on foxtail millet seedlings under salt stress. - Funct. Plant Biol. 46: 407-416, 2019.

Hu, L.X., Zhang, Z.F., Xiang, Z.X., Yang, Z.J.: Exogenous application of citric acid ameliorates the adverse effect of heat stress in tall fescue (Lolium arundinaceum) - Front. Plant Sci. 7: 179, 2016.

Jungklang, J., Saengnil, K., Uthaibutra, J.: Effects of water-deficit stress and paclobutrazol on growth, relative water content, electrolyte leakage, proline content and some antioxidant changes in Curuma alismatifolia Gagnep. cv. Chiang Mai Pink. - Saudi J. biol. Sci. 24: 1505-1512, 2017.

Kalhoro, N.A., Rajpar, I., Kalhoro, S.A., Ali, A., Raza, S., Ahmed, M., Kalhoro, F.A., Ramzan, M., Wahid, F.: Effect of salts stress on the growth and yield of wheat (Triticum aestivum L.). - Amer. J. Plant Sci. 7: 2257-2271, 2016.

Li, J.M., Hu, L.P., Zhang, L., Pan, X.B., Hu, X.H.: Exogenous spermidine is enhancing tomato tolerance to salinityalkalinity stress by regulating chloroplast antioxidant system and chlorophyll metabolism. - BMC Plant Biol. 15: 303, 2015.

Li, S., Jin, H., Zhang, Q.: The effect of exogenous spermidine concentration on polyamine metabolism and salt tolerance in zoysiagrass (Zoysia japonica Steud) subjected to short-term salinity stress. - Front. Plant Sci. 7: 1221, 2016.

Liu, J., Ishitani, M., Halfter, U., Kim, C. S., Zhu, J.K.: The Arabidopsis thaliana SOS2 gene encodes a protein kinase that is required for salt tolerance. - Proc. nat. Acad. Sci. USA 97: 
3730-3734, 2000.

Lou, Y.H., Guan, R., Sun, M.J., Han, F., He, W., Wang, H., Song, F.P., Cui, X.M., Zhuge, Y.P.: Spermidine application alleviates salinity damage to antioxidant enzyme activity and gene expression in alfalfa -. Ecotoxicology 27: 1323ł1330, 2018.

Lou, Y.H., Sun, X., Chao, Y., Han, F., Sun, M.J. Wang, T.T., Wang, H., Song, F.P., Zhuge, YP.: Glycinebetaine application alleviates salinity damage to antioxidant enzyme activity in alfalfa. - Pak. J. Bot 51: 19-25, 2019.

Maathuis, F.J.M., Amtmann, A.: $\mathrm{K}^{+}$nutrition and $\mathrm{Na}^{+}$toxicity: the basis of cellular $\mathrm{K}^{+} / \mathrm{Na}^{+}$ratios -. Ann. Bot. 84: 123-133, 1999.

Nahar, K., Hasanuzzaman, M., Alam, M.M., Fujita, M.: Exogenous spermidine alleviates low temperature injury in mung bean (Vigna radiata L.) seedlings by modulating ascorbate-glutathione and glyoxalase pathway. - Int. J. mol. Sci. 16: 30117-30132, 2015.

Porcel, R., Aroca, R., Azcon, R., Ruiz-Lozano, J.M.: Regulation of cation transporter genes by the arbuscular mycorrhizal symbiosis in rice plants subjected to salinity suggests improved salt tolerance due to reduced $\mathrm{Na}^{+}$root-to-shoot distribution. - Mycorrhiza 26: 673-684, 2016.

Puyang, X., An, M., Han, L., Zhang, X.: Protective effect of spermidine on salt stress induced oxidative damage in two Kentucky bluegrass (Poa pratensis L.) cultivars. - Ecotoxicol. Environ. Safety 117: 96-106, 2015.

Radhakrishnan, R., Lee, I.J.: Regulation of salicylic acid, jasmonic acid and fatty acids in cucumber (Cucumis sativus L.) by spermidine promotes plant growth against salt stress -. Acta Physiol. Plant. 35: 3315-3322, 2013.

Rasool, S., Ahmad, A., Siddiqi, T.O., Ahmad, P.: Changes in growth, lipid peroxidation and some key antioxidant enzymes in chickpea genotypes under salt stress -. Acta Physiol. Plant. 35:1039-1050, 2013.

Ruiz-Lozano, J.M., Porcel, R., Azcón, R., Aroca, R.: Regulation by arbuscular mycorrhizae of the integrated physiological response to salinity in plants: new challenges in physiological and molecular studies. - J. exp. Bot. 63: 4033-4044, 2012.

Sang, T., Shan, X., Li, B., Shu, S., Sun, J., Guo, S.R.: Comparative proteomic analysis reveals the positive effect of exogenous spermidine on photosynthesis and salinity tolerance in cucumber seedlings. - Plant Cell Rep. 35: 1769-1782, 2016.

Satish, L., Rency, A., Rathinapriya, P., Ceasar, S.A., Pandian, S., Rameshkumar, R., Rao, T.B., Balachandran, S.M., Ramesh, M.: Influence of plant growth regulators and spermidine on somatic embryogenesis and plant regeneration in four Indian genotypes of finger millet (Eleusine coracana (L.) Gaertn). Plant Cell Tissue Organ Cult. 124: 15-31, 2016.

Saxena, I., Srikanth, S., Chen, Z.: Cross talk between $\mathrm{H}_{2} \mathrm{O}_{2}$ and interacting signal molecules under plant stress response. Front. Plant Sci. 7: 570, 2016.

Shahbaz, M., Ashraf, M.: Improving salinity tolerance in cereals. - Crit. Rev. Plant Sci. 32: 237-249, 2013.

Sudhakar, C., Veeranagamallaiah, G., Nareshkumar, A., Sudhakarbatu, O., Sivakumar, M.: Polyamine metabolism influences antioxidant defense mechanism in foxtail millet (Setaria italica L.) cultivars with different salinity tolerance. Plant Cell Rep. 34: 141 156, 2015.

Taïbi, K., Taïbi, F., Abderrahim, L.A., Ennajah, A., Belkhodja, M., Mulet, J.M.: Effect of salt stress on growth, chlorophyll content, lipid peroxidation and antioxidant defense systems in Phaseolus vulgaris L. - South Afr. J. Bot. 105: 306-312, 2016.

Talaat, N.B., Ghoniem, A.E., Abdelhamid, M.T., Shawky, B.T.: Effective microorganisms improve growth performance, alter nutrients acquisition and induce compatible solutes accumulation in common bean (Phaseolus vulgaris L.) plants subjected to salinity stress. - J. Plant Growth Regul. 75: 281$295,2015$.

Tang, S., Zhang, H.X., Li, L., Liu, X., Chen, L., Chen, W.Z., Ding, Y.F.: Exogenous spermidine enhances the photosynthetic and antioxidant capacity of rice under heat stress during early grain-filling period. - Funct. Plant Biol. 45: 911-921, 2018.

Veeranagamallaiah, G., Jyothsnakumari, G., Thippeswamya, M., Reddy, C.O.P., Surabhia, G.K., Sriranganayakulua, G., Maheshb, Y., Rajasekharb, B., Madhurarekhab, C., Sudhakara, C.: Protemoic analysis of salt stress responses in foxtail millet (Setaria italica L. cv. Prasad) seedlings. - Plant Sci. 175: 631-641, 2008.

Wang, R.C., Chen, C., Guo, S.T.: Effects of drying methods on starch crystallinity of gelatinized foxtail millet ( $\alpha$-millet) and its eating quality. - J. Food Eng. 207: 81-89, 2017.

Zhang, L.Z., Liu, R.H.: Phenolic and carotenoid profiles and antiproliferative activity of foxtail millet. - Food Chem. 174: 495-501, 2015.

Zhang, N., Shi, X., Guan, Z., Zhao, S., Zhang, F., Chen, S., Fang, W., Chen, F.: Treatment with spermidine protects chrysanthemum seedlings against salinity stress damage. Plant Physiol. Biochem. 105: 260-270, 2016.

Zhao, Q., Bai, J., Lu, Q., Zhang, G.: Effects of salinity on dynamics of soil carbon in degraded coastal wetlands: implications on wetland restoration. - Phys. Chem. Earth Parts A/B/C 97: 1218, 2017.

Zhou, L., Zhou, H., Peng, Y., Zhang, X.Q., Ma, X., Huang, L.K., Yan, Y.H.: Exogenously applied spermidine improves drought tolerance in creeping bentgrass associated with changes in antioxidant defense, endogenous polyamines and phytohormones. - J. Plant Growth Regul. 76: 71-82, 2015. 